\title{
Caminhos para a inclusão
}

Juliana MANTELA TTO ${ }^{1}$

PACHECO, J. et al. Caminhos para a inclusão: um guia para o aprimoramento da equipe escolar. Porto A legre: Artmed, 2007.

José Francisco Pacheco é um educador português, especialista em Música e em Leitura e Escrita, é mestre em Ciências da Educação pela Faculdade de Psicologia e Ciências da Educação pela Universidade do Porto. Coordenador, desde 1976, da Escola da Ponte, da qual éideal izador. Instituição quese notabilizou pel o projeto educativo inovador, baseado na autonomia dos estudantes. A tuando na área, relata que o propósi to desta obra para o aprimoramento da equipeescolar, é distribuir aos professores, aos pais e aos serviços de apoio escolar elementos de práticas bem-sucedidas da educação escolar inclusiva.

A obra foi produzida durante os anos de 1998 a 2001 por uma equipe colaborativa da Áustria, da Islândia, dePortugal eda Espanha como partedo Projeto Leonardo da Vinci, denominado "Melhoramento da Habilidade dos Professores quanto à Inclusão (em inglês, ETAI). Tal projeto baseia-se em vários estudos de casos de esforços bem-sucedidos direcionados à educação inclusiva em escolas obrigatórias nos quatro países.

O livro está dividido em três partes. A primeira conceitua o projeto ETAI ea metodologia em que a pesquisa se baseou. A segunda parte reflete sobre os resultados do projeto em 10 capítulos, discutindo as implicações gerais de cada estudo. A terceira parte contém o "Guia para o aprimoramento da equipe escolar", dividido em 9capítulos correspondentes aos temas dos estudos de caso. A obra incluí, também, um CD-ROM com um vídeo, baseado em estudos de casos, com o propósito de introduzir vários aspectos da inclusão sobrea ótica dos participantes da pesquisa: alunos, pais, professores e especialistas nos serviços de apoio.

Como afirma o autor, a inclusão pressupõe que a escola se ajuste a todas as crianças que desejam matricular-se em sua localidade, em vez de esperar que uma determinada criança com necessidades especiais se ajuste à escola (isso seria apenas uma integração, não uma inclusão!).

\footnotetext{
${ }^{1}$ Mestranda do Programa de Pós-Graduação da Pontifícia Universidade Católica de Campinas. jumantelatto@hotmail.com
} 
Ao longo da obra, temas como: preparação para a educação escolar, planejamento curricular, prática em sala de aula, colaboração e coordenação, interação social dos alunos, colaboração lar-escola, aval iação e preparação, serviços deapoio e desenvolvimento de pessoal são abordados de modo que o leitor possa, rapidamente, compreender conceitos e aspectos relevantes.

Merecem destaque as sugestões de atividades no trabalho escolar voltad os para a prática de um cotidiano inclusivo. Tais atividades sugeridas fazemnos refletir: O que a inclusão real mente significa? Que tipo de educação e apoio a escola gostaria de fornecer a cada aluno? Quais são as barreiras para ajustar a aprendizagem às necessi dades individuais dos al unos na sala de aula? Como cada professor pode garantir que cada aluno possa expressar seus pontos de vista e seus sentimentos?

Resultados significativos do ETAI salientam quea essência da educação inclusiva é integrar todos os al unos na vida social dentro efora da escola. Pacheco destaca quea política ea organização da escola inclusiva precisam ser desenvolvidas pelo pessoal de ensino e pel os pais para construir uma cultura em que os alunos, os pais e os professores vivenciem os princípios da inclusão.

A aprendizagem cooperativa é ressaltada pelo autor, destacando que com a pesquisa pôdeafirmar que, por meio da cooperação, os al unos gradual mente desenvolvem várias habilidades, como por exemplo: perceber os outros e aceitálos com respeito, conhecer a si mesmos e sua função em grupo ou assumir responsabilidades uns pelos outros.

O livro foi pensado para ser utilizado em sessões de grupos regulares nas escolas. Cada parte e cada capítulo pode ser usado independentemente como material de discussão para o trabal ho de desenvolvimento da equipe docente, grupos de pais e especial istas. Com uma linguagem acessível, o Professor José Pacheco esua equi pe conseguem levantar, em linhas gerais, as principais questões sobre caminhos para a educação inclusiva. Traz informações úteis e que servirão como um ponto de partida para reflexões, não somente para profissionais desta área, mas a todos que queiram compreender o que a educação inclusiva pode proporcionar a nossa sociedade. 